—, and K. T. Hsich, 1959: Development of research on atmospheric circulation in our country in the past ten years. Acta Meteorol. Sinica, 30, 263-276. (JPRS 2654)

—, and H. L. Wang, 1965: A preliminary study of the instability and development of ultra-long waves. Acta Meteorol. Sinica, 35, 174-188. (AD 686 238)

*Zheng, C. J., 1963: The structure and seasonal activities of subtropical jet streams over the Tibetan Plateau. Acta Meteorol. Sinica, 33, 459-471.

\section{Numerical weather prediction}

Charney, J. G., and N. A. Phillips, 1953: Numerical integration of the quasigeostrophic equations for barotropic and simple baroclinic flows. J. Meteor., 10, 71-99.

Chen, Y. S., 1962: Response of the atmosphere to the solar actual direct radiation in a linear model of the long-range numerical prediction. Sci. Sinica, 11, 275-291.

* __, 1964: The long-range process of the general circulation of the atmosphere under the influence of nonadiabatic heating and the dynamic effect of orography. Acta Meteorol. Sinica, 34, 271-284.

- 1965: A numerical study of the general circulation of the atmosphere. Sci. Sinica, 14, 246-266.

_ et al., 1957: A test of a two-parameter model for a situation with a strong front. Acta Meteorol. Sinica, 28, 275-281. (Abstract in: Yao, Y. M., 1966: Bibliography on Numerical Prediction in Mainland China. U.S. Department of Commerce, Environmental Science Services Administration; Environmental Data Service, 26 pp.)

Chin, T. H., 1963: A dynamic model for the numerical prediction of baroclinic flows. Acta Meteorol. Sinica, 33, 131-144. (AD 623 117)

Chu, P. C., 1958: A hydrodynamical model for the seasonal variation of the general circulation and long-range forecasting. Acta Meteorol. Sinica, 29, 57-62. (AD 636 925)

- J. H. Wang, and M. T. Chao, 1961: A numerical model for long-range prediction considering the mutual adjustment of radiation and motion. Papers in Dynamical Meteorology, Memoir of the Institute of Geophysics and Meteorology, Academia Sinica, Peking, 96-106. (AD 631 031)

Chu, Y. T., 1961: A three-level nonlinear prediction model in spherical coordinates. Acta Meteorol. Sinica, 31, 216233. (AD 642 402)

Cressman, G. P., 1958: Barotropic divergence and very long atmospheric waves. Mon. Wea. Rev., 86, 293-297.

Fjørtoft, R., 1952: On a numerical method of integrating the barotropic vorticity equation. Tellus, 4, 179-194.
Kodaira, N., and Y. Masuda, 1965: On the 1964 Peking Symposium. Tenki, 12, 4-10 (in Japanese).

Liao, T. H., 1957: A simplified graphical method for numerical prediction with a two-parameter model. Sci. Sinica, 6, 191-202.

- 1958: A simplified two-layer model and its extension. Acta Meteorol. Sinica, 29, 162-175. (AD 675 137)

Lilly, D. K., 1961: A proposed staggered-grid system for numerical integration of dynamic equations. Mon. Wea. Rev., 89, 59-65.

*Liu, J. C., and Chao, 1962: A study of the speed of movement of pressure systems in a barotropic atmosphere. Acta Meteorol. Sinica, 32, 141-153.

—, and C. P. Chang, 1965: A numerical experiment using primitive barotropic equations. Acta Meteorol. Sinica, 35, 75-81. (JPRS 29516)

Lubkin, G. B., 1972: Physics in China. Phys. Today, 25, December, 23-28.

Oldham, C. H. G., 1969: Science travels the Mao road. Bull. Atomic Sci., 25, 80-83.

Phillips, N. A., 1956: The general circulation of the atmosphere: A numerical experiment. Quart. J. Roy. Meteor. Soc., 82, 123-164.

Sawyer, J. J., and F. H. Bushby, 1953: A baroclinic model atmosphere suitable for numerical integration. J. Meteor., $10,54-59$.

Shen, J. K., and W. F. Mou, 1965: A preliminary verification of 48-hour $500 \mathrm{mb}$ numerical prediction charts issued by the Central Weather Bureau. Acta Meteorol. Sinica, 35, 383-398. (JPRS 34925)

Staff of the Central Weather Bureau Numerical Forecast Section, 1965: Chinese numerical forecast service. Scientia, 2, 131-133. (JPRS 29516)

Staff of the Geophysics Research Center, Academia Sinica, 1959: China's achievements in numerical weather forecasting. Acta Meteorol. Sinica, 30, 236-242. (JPRS 2481)

Staff of the Institute of Computer Technology, Academia Sinica, 1965: Content Description of 103 Electronic Computer Programming. Peking, Science Press, 169 pp. (JPRS number unknown)

Thompson, P. D., and W. L. Gates, 1956: A test of numerical prediction methods based on the barotropic and twoparameter baroclinic models. J. Meteor., 13, 127-141.

Wolff, P. M., 1958: The error in numerical forecasts due to retrogression of ultra-long waves. Mon. Wea. Rev., 86, 245-250.

Yeh, T. C., and K. T. Hsieh, 1959: Development of research on atmospheric circulation in China from 1949 to 1959. Acta Meteorol. Sinica, 30, 263-276. (JPRS 2654)

\title{
announcements
}

\section{Atmospheric science at Texas Tech}

An undergraduate program in atmospheric science was recently initiated at Texas Tech University, Lubbock, Tex. The curriculum is one of several options available to students pursuing a Bachelor of Science degree in the

Department of Geosciences. The atmospheric science program includes 21 hours of formal course work in meteorology, in addition to a fixed core of courses in physics, mathematics, and related courses in geosciences. A graduate program in atmospheric science is in the planning stage; it is expected to have special emphasis in the areas of severe storms and atmospheric water resources.

Further information on the new program may be obtained by writing: Dr. Donald R. Haragan, Chairman, Department of Geosciences, Texas Tech University, P.O. Box 4109, Lubbock, Tex. 79409.

(More announcements on page 573) 
tation Dr. Myrup divided the problem into two parts: philosophical, which concerns the meteorology of the problem and the planning of urban growth which has been complicating the possible successful solution of meteorologically-related urban growth problems; and research into the meteorology that pertains to the planning function. Within the realm of problems associated with planning, consideration should be given to population growth, economic development, growth of energy demand. In this respect, Dr. Myrup considers that the "energy crisis" is actually a transportation crisis with the transportation of goods and people being both the largest polluter of the environment and the largest energy user.

Continuing the philosophical approach, Dr. Myrup turned to social development. Several items were listed: 1) planning consciousness - the "year 2000" approach based on the idea that the resources of the earth are finite; 2) a shift in emphasis and funding in the universities and other agencies to applied rather than pure or theoretical research; and 3) the "eco-boom" which has led to the proliferation of highly trained individuals. Dr. Myrup then turned to the role that meteorology and meteorologists play in this development, emphasizing regional and microscale meteorology as applied to the planning function. In the urban area, biometeorology, particularly as it applies to human health, and the urban climate are closely tied together. He forecast that this discipline may become the "science of the future."

Dr. Myrup then pointed out that legal measures can effect a coalition of meteorologists and planners, such as that found in the National Environmental Planning Act and the State (California) Environmental Planning Act. Both of these acts require "impact statements" on the effects of new construction on the environment. Most of Dr. Myrup's talk was illustrated by slides, including an important one showing the often interacting relationships between the factors comprising the whole urban-planning, air-quality planning problem. These factors include policy decisions and planning; land-use patterns; energy production and use (including pollution control technology); pollution emission; meteorological processes; wind transport and diffusion; the microclimate; air quality; human health and comfort; and monitoring processes. The above factors were displayed in a type of flow diagram and feed-back was shown.-Norman $S$. Benes and Arndt Lorenzen

The Sacramento Chapter held a meeting on 22 March with guest speaker Prof. Harry Dwyer, University of California at Davis, speaking on the global energy balance. The study project, sponsored by the National Science Foundation, had as its goal a sensitivity analysis of changes that could affect the long-term global energy balance and to evaluate the effects on world climate of such things as a possible change in the solar constant, increased energy production by man, changes in the carbon dioxide concentration in the atmosphere, and the effects of aerosols on global temperature change. A computer model was developed, in which the earth was subdivided into 18 latitudinal belts and the equations were solved by finite-difference techniques. Some of the results of this study include: 1) the large thermal capacity of the ocean produces a large dampening effect on global climatic changes; 2) the effects of climatic changes are small in equatorial regions and relatively large in the polar areas; and 3) the probable effect of increased energy production by man on the world climate is calculated to be small.

The meeting concluded with a question and answer period, at which time Prof. Dwyer reviewed several terms of the energy balance equation.-Charles Unger, Secy-Treas.

\section{Twin Cities}

The Twin Cities Chapter met on 15 February 1973 at the University of Minnesota. Mr. Gerry Bratt of the University gave a most interesting talk on "Models for Vortex Storms." Using liquids of different densities and rotating the lower liquid only, he demonstrated that the funnel consisted of liquid from the upper layer, which circulated into the funnel center, and back up along the sides of the funnel without mixing with the lower layer liquid. Mr. Bratt agreed to repeat the demonstration during the tornado season.

The 22 March meeting of the Chapter was held at the University of Minnesota. Fifteen members and guests were present to hear Mr. Arthur Belmont speak on Stratospheric Circulation and Climate. Mr. Belmont gave a most interesting talk and showed slides and movies on the semi-annual stratospheric changes, and also talked on and showed slides on stratospheric warming.-John J. Parry, Secy.

\section{West Central Florida}

The University of South Florida's Geography Department was the host for the 15 February meeting of the West Central Florida Chapter. Dr. Robert Fuson introduced Prof. Cecil Palmer who spoke on "The Influence of Climatology on Colorado Mining Towns."

The 15th of March was the date of the annual banquet, held at the Causeway Inn South in Tampa. Merrit Techter, Chief of the Systems Development Branch, National Weather Service, was the speaker for the evening.

Many local chapter members were in attendance at the AMS Annual Meeting, held at the Hilton Hotel in St. Petersburg, 29 January-1 February.-Charles Fetherston, Corres.
(Continued from announcements, page 518)

\section{Climate and living comfort symposium}

An International Symposium on Building Climatology, Climate and Living Comfort, will be held in Zurich, Switzerland, 25-27 September 1974. The reasons for the symposium are the outstanding success of the symposium conducted by the International Council for Building Research Studies and Documentation in Stockholm in 1972 and the growing importance of utilizing meteorological, climatological, and physiological knowledge in building practice and planning. The symposium is being held in cooperation with the
World Meteorological Organization and the International Federation for Housing and Planning.

During the course of the symposium the problems of the environment, physics, medicine as related to building research, education, construction and architecture will be dealt with, as will the climatological problems involved in local and regional planning. As a public symposium to be held in the English, German, and French languages, the gathering will be open to all interested professionals. Application data can be requested from the Symposium Secretariat, Swiss Building Documentation, CH-5259 Blauen, Switzerland.

(More announcements on page 578) 


\section{at AMS neadquaplers}

On the 1st of April Executive Director Spengler was in Mainz, Germany, for the International Symposium on Atmospheric Trace Gases sponsored by the International Union of Geodesy and Geophysics in cooperation with the AMS and the World Meteorological Organization. He hosted an AMS reception on the 2nd for participants in the Symposium. While in Germany, Mr. Spengler also visited Headquarters of the 2nd Weather Wing of the Air Force's Air Weather Service in Wiesbaden.

The Woods Hole Executive Committee held its monthly meeting at 45 Beacon St. on 4 April.

Mr. Spengler returned to Boston on 6 April in time to greet Brig. Gen. Bengt A. Bengtsson, Commander of the Royal Swedish Air Force's Military Weather Service, and his staff, Lt. Col. Arne E. Jonason, Director of Administration and Training, and Lt. Col. Bengt O. Soderberg, Director of Research and Development on the $7 \mathrm{th}$. Accompanying the Swedish officers were the U.S. Air Weather Service's Col. Dale J. Flinders and Maj. John A. Lasley, Jr. (see page 550).

The Executive Director attended the spring meetings of the American Geophysical Union and the AMS during the week of 16 April in Washington, D.C. He also attended the presentation of the Air Transport Association's Gorell Award to AMS Past President Arthur F. Merewether and Past Vice President Henry T. Harrison (see Special News Feature, page 558).

On 19 April, Mr. Spengler met with Publications Commission Chairman Dr. Glenn R. Hilst, and Dr. S. I. Rasool, Editor of the Journal of the Atmospheric Sciences, and Dr. Edward S. Epstein, Editor of the Journal of Applied MeteORoLOGY, to discuss the relationship of the AMS journals with the Monthly Weather Review. During the evening of the 19th, the Executive Director attended the first meeting of the U.S. National Committee for the International Union for Geodesy and Geophysics in Washington.
The AMS Board of Admissions met at Society headquarters on 24 April. Attending were: Chairman, Arnold A. Barnes, Jr., Air Force Cambridge Research Laboratories; and Members, Robert C. Curtis, Lowell Technological Institute; Robert E. Lautzenheiser, National Weather Service; and Peter R. Leavitt, Northeast Weather Service.

Mr. Spengler attended a briefing at the United Nations on 25 April on the development of United Nations environment programs, given by Mr. Noel J. Brown, Liaison Officer in charge of the New York Office of the UN Environment Program. While in New York Mr. Spengler also met with the treasurer and director of publications of the American Institute of Physics to discuss matters of mutual interest.

During April the following were among visitors to the AMS: James W. Fullmer; M. Seymourian, New York City; Joe Bale, Washington, D.C.; Robert F. Wise, New York City; Deborah A. Limerick, Boston, Mass.; Mrs. Rolf E. Johnson, Nazareth, Pa.; Mrs. Beverly Menzes, Reading, Pa.; Paul M. Fye, Woods Hole, Mass.; Noel B. McLean, Long Island, N.Y.; Robert H. Cole, Woods Hole, Mass.; Mary Sears, Woods Hole, Mass.; Art Maxwell, Woods Hole, Mass.; N. Horner, Woods Hole, Mass.; David Scott, Woods Hole, Mass.; E. M. Brooks, Woods Hole, Mass.; H. Brooks, Cambridge, Mass.; Navias Cuelder, Woods Hole, Mass.; Cosmo Vaudo, Somerville, Mass.; Simone Anthreurz, Swampscott, Mass.; C. Russell Walton, Boston, Mass.; Barbara Housen, Shrewsbury, Mass.; John C. Beckman, Etna, Calif.; Robert Lynch, Boston, Mass.; Robert J. Wise, Ephrata, Pa.; David Green, Boston, Mass.; Irving Gringorten, Hanscom Field, Mass.; Joseph Segrt, Framingham, Mass.; John W. Evans, Cambridge, Mass.; R. R. Mullany, St. Paul, Minn.; Can Nelairissej, Concord, N.H.; Kenneth L. Allen, Holden, Mass.; I. L. Harvey, Boston, Mass.; Mr. and Mrs. Alden V. Teschke, Trenton, N.J.; Bruce C. Weller, Newport, R.I.; Holly Hackman, Boston, Mass.; Mrs. E. J. Hackman, Warwick, R.I.; Nancy Ellen Hackman, Newton, Mass.; Bruce Hackman, Swampscott, Mass.; Karen Smith, Somerville, Mass.; Lorraine Rushton, Westwood, N.J.; Mark Rushton, Westwood, N.J.; Helen Rountree, Boston, Mass.; Gerald A. Peterson, Wheaton, Mass.; J. H. Junian, Burlington, Mass.; Milt Levine, Rockville, Md.; Dr. Fruwaldrop, Rockville, Md.; Abe S. Abraham, Rockville, Md.; Frank F. Russell, Boston, Mass.; Maria A. Irwin, Boston, Mass.

(Continued from announcements, page 573)

\section{NTIS/SSIE cooperation}

Over 400,000 reports on government research projects recently became publicly available when the National Technical Information Service and the Smithsonian Science Information Exchange began coordinating their computer search services. NTIS, an agency of the Department of Commerce, has been providing subject searches of over 300,000 reports on government research completed since 1964, while SSIE has been providing a similar service on about 100,000 ongoing government research projects. As a result of the coordination the computerized collections of both agencies may be searched simultaneously and the results combined in one package for NTIS customers.

A single search provides research abstracts from the information files of both NTIS and SSIE. The package, priced at $\$ 85.00$ for the first 125 abstracts, gives the search user a $\$ 15.00$ savings over the cost of the two separate searches

formerly required to cover both information bases. Users are charged 25 cents for each abstract over the initial 125. Computer print-outs which summarize activity in specific fields of interest are provided to users of the NTIS/SSIE Search Service. For further information contact: NTIS, U.S. Department of Commerce, Port Royal Road, Springfield, Va. 22151; the telephone for the NTIS/SSIE Search Service is 703-321-8523, Telex 89-9405.

\section{NTIS begins TELEX service}

The National Technical Information Service, distributor of many government scientific publications, has begun serving the public through the TELEX service, Western Union's World-wide direct dial teleprinter-to-teleprinter exchange service. The NTIS TELEX number is 89-9405; it is usable 24 hours a day, 365 days a year, and can be used to order documents and begin NTISearches. The address for NTIS is U.S. Department of Commerce, Springfield, Va. 22151.

(More announcements on page 589) 


\section{Modeling the ice age climate}

The National Center for Atmospheric Research's global circulation model is being used to simulate the climate of the last glacial maximum $(200,000$ years ago) by researchers at the Institute of Arctic and Alpine Research, University of Colorado, Mrs. Jill Williams, a doctoral candidate at the University, Dr. R. G. Barry of the Institute, and Dr. W. M. Washington of NCAR. The changed boundary conditions include ocean surface temperatures, snow and ice cover, and land albedos.

Simulation runs for January and July control cases and glacial maximum cases show that the July mean zonal westerlies in the Northern Hemisphere at glacial maximum were similar to present winter conditions. Zones of cyclonic activity were displaced southward in the Northern Hemisphere in January, and in July there were major storm tracks across the North Atlantic and from eastern Europe into Asia. Changes in precipitation were primarily quantitative rather than in its spatial distribution. A dramatic reduction of precipitation in the Northern Hemisphere in July is indicated.

Analyses of momentum and energy budgets are in progress, and the application of the results to an assessment of oceanic conditions is planned. The basic results for the four cases are documented in INSTAAR Occasional Paper No. 5/NCAR Ms. No. 2120-73-8, of which a limited number of copies are available on request.

\section{Ecology action notes}

The Battelle-Northwest Laboratories are currently investigating a new method for capturing .05 - to $.5-\mu \mathrm{m}$ size industrial air pollutants. The demonstration research program, under a $\$ 36,500$ grant from the Environmental Protection Agency, using a new technique of electrostatic precipitation to remove particulates from the atmosphere and has, according to Dr. Arlin K. Postma, Manager of the study, already demonstrated high efficiency. With the new process, air flow is directed through a corona charge which imparts a negative electrical charge to the suspended particles which then collect downstream on dry, open-weave fiber beds. Periodically the fiber beds are washed in place and the cycle continues. Current electrostatic precipitation processes usually employ a series of oppositely charged collecting plates; the Battelle system permits like-charged particles to deposit themselves on nonconducting fibers. Tests have demonstrated a $95 \%$ operational efficiency for removal of submicron particles at airstream velocities of $300 \mathrm{ft} \mathrm{min}^{-1}$. Conductive and non-conductive particulates will be generated into a precipitator at the Battelle-Northwest laboratory to study a variety of conditions which will simulate the composition of aerosols generated in various smelting and production operations.

* * *

As a major step in the National Aeronautics and Space Administration's Global Air Sampling Program (GASP), a Boeing 747 will be outfitted with instruments for pollution monitoring of the upper atmosphere. Airlines, airframe, and avionics systems manufacturers submitted proposals by 2 April on a contract covering the design and fabrication of a system of instruments to sample gaseous and particulate pollutants, installation of the instruments, and flight testing. The GASP contract provides NASA with the option of equipping a second Boeing 747 with air monitoring instruments. Scientists managing the program from NASA's Lewis Research Center in Cleveland plan ultimately to outfit between 10 and 15 foreign and domestic commercial planes so that global coverage of pollution levels can be obtained.

When the bids have been reviewed by a NASA source evaluation board the cost-plus-fixed fee contract will be awarded in July. Air monitoring instruments will be located on the underside of the nose just below the first class compartment of the planes; they are safe, noiseless, and will not interfere with airline operations.

\section{* * *}

As a result of work done at The Pennsylvania State University a new possibility of reducing smog without reducing automobile exhaust emissions has been developed. A group led by Dr. Julian Heicklen has, after five years, elucidated the precise pathway by which hydrocarbons and nitric oxide are transformed into photochemical smog. Funded by the Environmental Protection Agency, the group found that the most vulnerable point in the process is a self-sustaining chain in which atmospheric nitric oxide, in the presence of hydrocarbons and UV radiation produces $\mathrm{NO}_{2}$ and ultimately ozone, the principal culprit in photochemical smog. What the investigators have done is to break the chain by using inhibitors that block the intermediate chain, thus preventing production of smog. Not only would the use of a smog inhibitor reduce the amount of atmospheric ozone, it would also prove much less expensive and less technically difficult than current attempts to cut emissions through converter devices, or changes in fuel type. Heicklen and his co-workers have found three inhibiting compounds to date, the most successful of which was aniline. But Heicklen admits that the side-effects of this inhibitor have not been thoroughly examined yet, nor has it been tested under actual atmospheric conditions.
(Continued from announcements, page 578)

\section{Meetings of interest}

28-30 August: An International Conference on Radiation and Remote Probing of the Atmosphere will take place at the University of California, Los Angeles. Contact: Dr. J. G. Kiriyan, International Conference on Radiation, Department of Meteorology, University of California at Los Angeles, Los Angeles, Calif. 90024.

9-12 September: A Symposium on Aeronomy of the Stratosphere and Mesosphere, the Second General Scientific Assem- bly of the International Association of Geomagnetism and Aeronomy will be held in Kyoto, Japan. Contact: Prof. H. I. Schiff, York University, Toronto, Ontario, Canada.

10-15 September: The 9th Annual Marine Technology Society Conference and Exposition will be held in Washington, D.C., at the Sheraton-Park Hotel, with the short course, "Planning for Offshore Ports," from 10-15 September. Contact: Marine Technology Society, 1730 M St., N.W., Washington, D.C. 20036.

18-20 September: The Symposium on Marine Geodesy will be held at Battelle Memorial Institute, Columbus Labora- 
tories, sponsored by the International Association of Geodesy. Contact: A. G. Mourad, Battelle, Columbus Laboratories, 503 King Ave., Columbus, Ohio 43201.

24-28 September: The First World Conference on Water Resources will be held in Chicago, Ill., with the theme "Water for the Human Environment," sponsored by the International Water Resources Association. Contact G. M. Karadi, Secretary General IWRA, Science Complex Building, University of Wisconsin, Milwaukee, Wis. 53201.

25-28 September: Ocean '73, the International Conference of the Institute of Electrical and Electronic Engineers, Inc., on Engineering in the Ocean Environment, will be held at the Washington Plaza Hotel, Seattle. Contact: Ocean '73, University of Washington, Applied Physics Laboratory, 1013 N.E. 40th St., Seattle, Wash. 98195.

2-5 October: A meeting on Remote Sensing in Oceanography will be held in Orlando, Fla. Contact: P. G. Teleki, Coastal Engineering Research Center, 5201 Little Falls Road, N.W., Washington, D.C., 20016.

\section{New publications}

Advances in aerosol physics, Volume 2 (V. A. Fedoseev, editor, 1972, 172 pp., \$15.00, from Halsted Press, Sales Division, 605 Third Ave., New York, N.Y. 10016) contains items on physics of water aerosols, combustion of disperse systems, gas dynamics of aerosol systems.

Aerosols and atmospheric chemistry (G. M. Hidy, editor, 1972, xviii + 348 pp., \$14.50, from Academic Press, Inc., 111 Fifth Ave., New York, N.Y. 10003) covers a wide variety of studies on the physical chemistry of aerosols and their relationship to atmospheric chemistry.

Atmospheric sampling and analytic devices for monitoring and detection of pollutants (NTIS-PK-154, NTIS, January 1973, 121 pp., \$20.00, from National Technical Information Service, U.S. Department of Commerce, Springfield, Va. 22151) contains selected abstracts on 120 research reports on smoke detectors, gas detectors, chemical indicators, infrared detection, radiation measurement instruments, and various methods for sampling the atmosphere for pollution control.

Conservation in the Soviet Union (Philip R. Pryde, 1972, 301 pp., \$12.50 clothbound, from Cambridge University Press, American Branch, 32 East 57th St., New York, N.Y. 10022) is the first systematic and comprehensive survey in English of resource management in the Soviet Union, analyzing attitudes and accomplishments in the field of conservation of natural resources.

Disaster by oil: Oil spills: Why they happen, what they do, how we can end them (Jeffrey Potter, 1973, 301 pp., $\$ 7.95$, from The Macmillan Company, 866 Third Ave., New York, N.Y. 10022) presents case studies of supertankers and their oil spill disasters, the effects they have, and the steps that can be taken to end the problem.

EBBA: An energy budget programme (Publication in Meteorology, No. 105, E. Vowinckel and Svenn Orvig, May 1972, 50 pp., n.p., from Arctic Meteorology Research Group, Department of Meteorology, McGill University, Montreal, Quebec, Canada) is a description of an energy budget (heat and water budgets) program which has been developed over a period of six years.

\section{OPPORTUNITY KNOCKS}

\begin{abstract}
Air Weather Service (AWS) has several Mobilization Augmentee positions vacant for prior service enlisted Weather Equipment Technicians, Forecasters, and Observers in grades of Sergeant through Senior Master Sergeant. Weather technicians participating in this program are required to train only one day per month and perform one two-week annual tour of active duty. The AWS program has a distinct advantage over other Reserve programs. Personnel are assigned to HQ AWS, Scott AFB IL, but perform training at a Regular Air Force weather unit in the vicinity of their home. Training is accomplished on the latest Air Force equipment under the supervision of qualified Air Weather personnel. Pay and promotional opportunities are excellent. Personnel interested in this program should contact HQ MAC/DPB, Scott AFB IL 62225.
\end{abstract}

The effect of thermometer screen design on the observed temperature (WMO No. 315, W. R. Sparks, 1972, 106 pp., n.p., from UNIPUB, Box 433, New York, N.Y. 10016) is a review of a large number of published studies to identify the aspects of thermometer screen design, exposure, and use that affect the temperature measured inside the screen. In addition, there is an extensive bibliography and a survey of the types of thermometer screens currently used by meteorological services.

Engineering and development program plan-all weather landing (AD-754 264, Federal Aviation Administration, October 1972, 39 pp., $\$ 3.75$, from NTIS, above) includes investigation of advanced technology on continuing and long-term development, plus work on advanced cockpit displays and airport lighting techniques. Related efforts include applications to all weather landing operations, advanced weather measuring and fog dispersal techniques.

Environmental geoscience: Interaction between natural systems and man (Arthur N. Strahler and Alan H. Strahler, 1973, 511 pp., il., $\$ 12.95$ hardbound, from Hamilton Publishing Company, A Division of John Wiley \& Sons, Inc., Publishers, 605 Third Ave., New York, N.Y. 10016) contains chapters on: energy systems of the atmosphere and hydrosphere; energy systems of the lithosphere; energy systems at the fluid-solid interface; and flow of energy and matter in the biosphere.

Environmental pollution and climatic change (AFCRL-TR72-0010, Translations No. 101, Chotaro Nakajima et al., 
January 1973, 44 pp., n.p., from Air Force Cambridge Research Laboratories (OPA), L. G. Hanscom Field, Bedford, Mass. 01730) discusses environmental pollution and climatic change, beginning with atmospheric pollution on a global scale, followed by anthropogenic modification of global climate, numerical experiments on climatic change, cooling in the Northern Hemisphere, environmental influence on the Japan climate, climatic variation related to the mass of perennial snow patches, and secular variations of air temperature and humidity in some suburban localities.

Fifth annual survey report on the Air Weather Service weather modification program (FY 1972) (TR 259, Herbert S. Appleman, Ted S. Cress, Robert I. Sax, and Klaus M. Weickmann, December 1972, 14 pp., n.p., from Headquarters Air Weather Service, Scott AFB, Ill. 62225) covers the projects, their operation and results, undertaken by the AWS on weather modification during FY 1972.

Fundamentals of air pollution (Samuel J. Williamson, 1973, 472 pp., il., $\$ 14.95$ hardbound, from Addison-Wesley Publishing Company, Inc., Reading, Mass. 01867), written for the one-semester course in air pollution for advanced undergraduates and graduates, this interdisciplinary text draws on the atmospheric sciences, physics, engineering, chemistry, medicine, and psychology, to relate the causes, evolution, and effects of air pollution.

Guide to American scientific and technical directories (First edition, Bernard Klein, 1973, 336 pp., \$25.00 hardbound, from B. Klein Publications, Inc., 11 Third St., Rye, N.Y. 10580 ) is divided into over 100 categories; it gives complete information on each directory listed including description of contents, frequency of publication, name and address of publisher, and price if any.

Heat and concentration waves: Analysis and applications (G. Alan Turner, 1972, 249 pp., \$16.50, from Academic Press, above) deals with two main aspects of traveling waves of temperature and dissolved materials. First, it shows how the measurements of these waves can be used to determine physical or chemical quantities. Second, by demonstrating their similarities to and contrasts with more conventional waves, it shows that these waves are of interest in their own right.

Morphology of the earth in the antarctic and subantarctic, Folio 16 (Antarctic Map Folio Series, Bruce C. Heezen, Marie Tharp, and Charles R. Bentley, 1972, 8 plates, 16 pp., $\$ 13.00$ plus $\$ 1.00$ postage and handling prepaid, plus $\$ 1.00$ extra if plates 1 and 3 are sent unfolded, from American Geographical Society, Broadway at 156th St., New York, N.Y. 10032) gives cartographic features of the ocean floors for the area designated.

The following NOAA Technical Reports are now available: Cloud motions in baroclinic zones (NOAA TM NESS 43, COM-72-10029, Linwood F. Whitney, Jr., October 1972, 6 pp., n.p., from NTIS, above).

Convective clouds as tracers of air motion (NOAA TM NESS 40, COM-72-11421, Lester F. Hubert and Andrew Timchalk, July 1972, 12 pp., n.p., from NTIS, above).

\section{GLOSSARY OF TERMS FREQUENTLY USED IN AIR POLLUTION} (approx. 275 terms) $\$ 2.00$

\section{GLOSSARY OF TERMS FREQUENTLY USED IN WEATHER MODIFICATION (approx. 455 terms) $\$ 2.00$ edited by Ralph E. Huschke}

$\mathrm{T}$ hese pocket glossaries $\left(8^{\prime \prime} \times \frac{1}{2}^{\prime \prime}\right)$ were compiled for use at two seminars sponsored by the American Meteorological Society to acquaint science writers with basic and up-to-date knowledge about two topics of great current interest and importance. Though compact, they are comprehensive references to technical terms often encountered in the literature on air pollution and weather modification. The definitions, though rigorous, are phrased in language readily understandable to students and teachers, science writers, scientists in non-meteorological disciplines, and layman interested in the physical environment.

M eteorology affects every human activity, and those engaged in the most diverse occupations find themselves considering it more and more frequently in their planning, production, and communication. Projects directed at environmental improvement are under way from the research laboratory and the manufacturing plant to the farm and the classroom. Air pollution is one of our most immediate problems and weather modification one of our most promising paths of scientific research. The glossaries should prove an indispensable reference for non-meteorologists concerned in any way with these two fields, whose ramifications extend far beyond the sphere of meteorology.

Send orders to:

AMERICAN METEOROLOGICAL SOCIETY, 45 BEACON STREET, BOSTON, MASS. 02108 
Cumulus clouds and their modification (NOAA TM ERL OD-14, COM-72-10791, Joanne Simpson and Arnett S. Dennis, May 1972, 147 pp., $\$ 3.00$ paper copy, 95 cents microfiche, from NTIS, above).

Evaluation of a technique for the analysis and forecasting of tropical cyclone intensities from satellite pictures (NOAA TM NESS 42, COM-72-11472, Carl O. Erickson, September 1972, 28 pp., n.p., from NTIS, above).

Flash flood forecasting and warning program in the western region (NOAA TM NWS WR-82, Philip Williams, Jr., Chester L. Glenn, and Roland L. Raetz, December 1972, 12 pp., n.p., from NTIS, above).

Mean diurnal and monthly height changes in the troposphere over North American and vicinity (NOAA TM NWS TDL-47, COM-72-11132, August F. Korte and DeVer Colson, August 1972, 30 pp., n.p., from NTIS, above).

Monthly climatological charts of the behavior of fog and low stratus at Los Angeles International Airport (NOAA TM NWS WR-76, COM-72-11140, Donald M. Gales, July 1972, 46 pp., $\$ 3.00$ paper copy, 95 cents microfiche, from NTIS, above).

Objective method of forecasting summer thunderstorms (NOAA TM NWS ER-46, COM-72-10765, John F. Townsend and Russell J. Younkin, May 1972, 9 pp., n.p., from NTIS, above).

An objective method of preparing cloud cover forecasts (NOAA TM NWS ER-47, COM-72-11382, James R. Sims, August 1972, 6 pp., n.p., from NTIS, above).

PEATMOS probability of precipitation forecasts as an aid in predicting precipitation amounts (NOAA TM NWS ER 50, COM-72-10243, Stanley E. Wasserman, December 1972, 11 pp., n.p., from NTIS, above).

A procedure for improving National Meteorological Center objective precipitation forecasts (NOAA TM NWS ER-49, COM-72-10132, Joseph A. Ronco, Jr., November 1972, 9 pp., n.p., from NTIS, above).

A selected annotated bibliography of the climate of the Great Lakes (NOAA TM EDS BS-72, COM-72-10830, Henry Hacia, March 1972, 60 pp., $\$ 3.00$ paper copy, 95 cents microfische, from NTIS, above).

A technique for the analysis and forecasting of tropical cyclone intensities from satellite pictures (NOAA TM NESS 36, COM-72-10840, Vernon F. Dvorak, June 1972, 17 pp., n.p., from NTIS, above).

Photochemical smog and ozone reactions (Advances in Chemistry Series, No. 113, 1972, 285 pp., \$14.95 clothbound, from American Chemical Society, 1155 Sixteenth St., N.W., Washintgon, D.C. 20036) presents current research into the chemical behavior of ozone and deals with practical problems of pollution. Papers are presented from two symposia sponsored by Division of the ACS at the 161st ACS meeting in Los Angeles, 29 March 1971 and 1 April 1971.

Photogrammetry and photo-interpretation applied to analyses of cloud cover, cloud type, and cloud motion (NASA TM X-
64710, Paul A. Larsen, June 1972, 78 pp., $\$ 3.00$ paper copy, from NTIS, above).

Proceedings for the International Symposium on Uncertainties in Hydrologic and Water Resource Systems (3 volumes, $\$ 22.00$ per set, payable to International Symposium on Uncertainties in Hydrologic and Water Systems, from Department of Hydrology and Water Resources, 200E Old Psychology Building, University of Arizona, Tucson, Ariz. 85721) contains proceedings of the symposium held 11-14 December 1972 at the University of Arizona.

Proceedings of the colloquium on conservation problems in Antarctica (Bruce C. Parker, editor, 1972, 356 pp., \$10.00, from Dr. Bruce C. Parker, Department of Biology, Virginia Polytechnic Institute and State University, Blacksburg, Va. 24061) attempts to confront many present and future problems and their consequences in Antarctica and its circumpolar waters. The three-day conference focuses primarily on the problem of U.S. bases and operations because it was felt that each nation that signed the Antarctic Treaty is the best judge of its own problems.

Radar meteor trail test final report (AFCRL-72-0190, Environmental Research Papers No. 397, Arnold A. Barnes, Jr.. 1972, 41 pp., n.p., from NTIS, above).

Radar meteor winds at Eglin AFB, Florida (AFCRL-72-0186, Environmental Research Papers No. 393, Arnold A. Barnes, Jr., 1972, 32 pp., n.p., from NTIS, above) gives results of comparison of winds obtained by the Stanford University Mark II Radar Meteor Trail System when it was moved to Elgin AFB, Fla., for field testing, with those obtained by the rocket, chemical release method and the radar meteor method.

Research and monitoring: Cornerstone for environmental action (Environmental Protection Agency, October 1972, 16 pp., il., 50 cents, from Superintendent of Documents, U.S. Government Printing Office, Washington, D.C. 20402) describes some of the EPA's research and monitoring programs and some of the pollution problems.

A study of numerical simulation of maritime fog (ENVPREDRSCHFAC TP No. 13-72, David M. Felt, December 1972, 31 pp., n.p., from Environmental Prediction Research Facility, Naval Postgraduate School, Monterey, Calif. 93940) reports the findings of an investigation into the use of a numerical advection fog model in a maritime environment.

A summary of cloud seeding activities conducted over the Kings River Watershed during the period May-September 1972 (Prepared by Thomas J. Henderson for the Kings River Conservation District, Fresno, Calif., December 1972, 32 pp., n.p., from Atmospheric Incorporated, 5652 East Dayton Ave., Fresno, Calif.).

Waves on beaches and resulting sediment transport $(\mathbf{R}$. E. Meyer, editor, October 1972, 472 pp., \$16.00, from Academic Press, above), the proceedings of an advanced seminar conducted by the Mathematics Research Center, the University of Wisconsin, and the Coastal Engineering Research Center, U.S. Army, at Madison, Wis., 11-13 October 1971, this book offers an interdisciplinary view of the present state of physical research in coastal oceanography-and of the rapid progress made in the field in the last decade. 